\title{
When did the mistletoe family Loranthaceae become extinct in Tasmania? Review and conjecture
}

\section{Mike Macphail}

Department of Archaeology and Natural History, College of Asia and the Pacific, The Australian National University, Canberra, ACT

mike.macphail@anu.edu.au

\section{Greg Jordan}

University of Tasmania, Hobart, Tasmania

\section{Feli Hopf}

The Australian National University, Canberra, ACT

\section{Eric Colhoun}

University of Newcastle, Newcastle, NSW

\section{Introduction}

'Mistletoe' is the common name for a diverse group of hemi-parasitic shrublets that grow attached to and within the branches of trees and shrubs. Vidal-Russell and Nickrent (2008a) and Nickrent et al. (2010) infer that the mistletoe habit has evolved five times in the sandalwood order Santalales. The first of these clades is the family Misodendraceae, which is endemic to southern South America and whose species grow mainly on Nothofagus. The habit evolved three times within the Santalaceae - in the cosmopolitan tribe Visceae, which includes the 'archetypal' European Mistletoe Viscum album, in tropical American species of Santaleae that were formerly placed into a separate family, the Eremolepidaceae, and in the tropical tribe Amphorogyneae. The third clade comprises all members of the Loranthaceae except the early diverging genera Nuytsia and Atkinsonia. The family is restricted to the Southern Hemisphere except for a few 
genera growing north of the equator in the tropics and around the Mediterranean.

Two mistletoe clades are extant in Australia. These are (1) Visceae (three genera including Viscum), which is restricted to rainforests, monsoon forests and woodlands along the northern and eastern margins, and (2) Loranthaceae (12 genera), which is widely distributed across mainland Australia, with hosts ranging from coastal mangrove forests to mulga (Acacia aneura) woodlands in the arid zone (www.anbg.gov.au/abrs/online-resources/flora/redirect.jsp). Two Australian species are root parasites and for this reason give the appearance of being stand-alone shrubs or small trees - Nuytsia floribunda, which is endemic to southwest Western Australia, and Atkinsonia ligustrina, which is confined to exposed habitats in the Blue Mountains of NSW (Barlow 1984).

No mistletoes now occur in Tasmania. The reason(s) for this remain obscure given the wide ecological tolerance of many genera within the Loranthaceae and their observed dispersal over long distances by birds (www.anbg.gov.au/mistletoe/remote-islands.html). In this review, we illustrate and discuss the implications of Loranthaceae-type pollen recovered from a range of offshore and onshore sites around Tasmania (Figure 1). Unlike many fossil angiosperm pollen types, the morphology of these specimens is sufficiently distinctive to allow them to be assigned to this family and one of the six fossil species possibly to an extant genus.

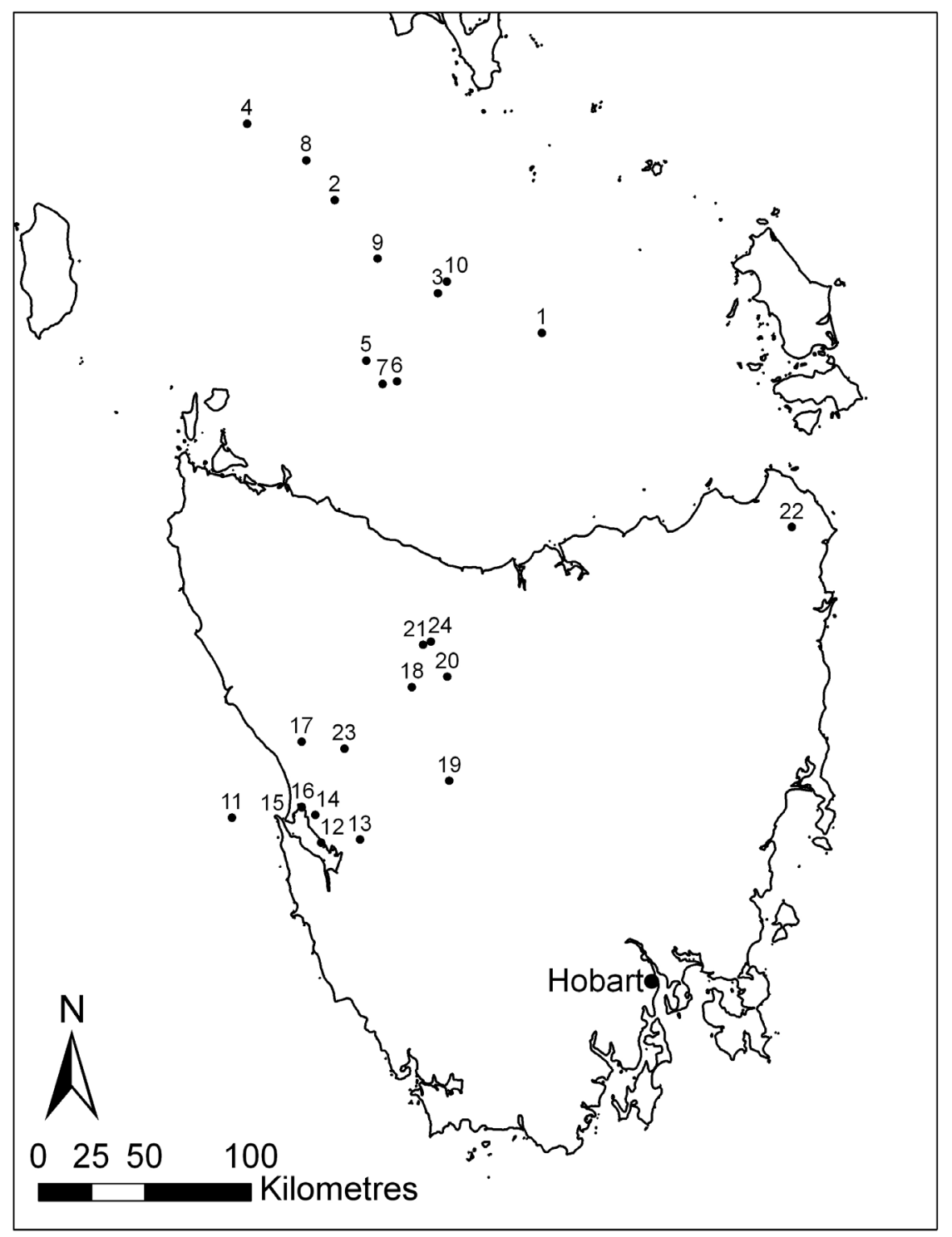

Figure 1. Location of sites mentioned in the text. 


\section{Loranthaceae pollen}

Modern Loranthaceae pollen comprise two morphologically distinct types, one of which is a \pm convex triangular, oblate grain with simple to complex tricolpate (rarely syncolpate) apertures, e.g. Alepis, Amyema, Amylotheca, Decaisnia, Peraxilla and Nuytsia, and the other of which is a sphaeroidal, triporate to tricolporoidate grain ornamented with stout spines (baculae, echini), e.g. Lepidoceras (Chile) and Tupeia (NZ) (see Erdtman 1966; Heusser 1971; Moar 1993; Beug 2004).

Pollen produced by Loranthaceae genera (Figures 2a-o) are easily distinguished from other Australian pollen morphotypes. Key characteristics are: (a) the oblate, triangular to lobate shape, (b) thin exine except across the poles where distinctively sculptured or thickened exine may form a bluntly triangular 'bridge' (Pocknall and Mildenhall 1984) or 'apical cushion' (Mildenhall and Pocknall, 1989), respectively, and (c) apertures (colpi) located at the tips (angles) of rounded to truncated apices. The usually gaping, colpate to demicolpate apertures vary in length from relatively short, in, for example, Amylotheca, to extremely long, in, for example, Amyema and Peraxilla. Ornamentation in the mesocolpial regions varies from psilate-scabrate to verrucatebaculate. In some genera, the tectum breaks down to form a pseudo-reticulum, e.g. Nuytsia; more rarely, the colpi are bordered by very short parallel rods (striae) that may extend close to the poles, e.g. Alepis and Peraxilla.

Australian fossil pollen types displaying the same morphological characteristics have been assigned to, or compared with, six formally described species: 'Amylotheca' pliocenica Cookson 1957, Gothanipollis bassensis Stover and Partridge 1973, Gothanipollis gothani Krutzsch 1959, Gothanipollis perplexus Mildenhall and Pocknall 1984, Tricolpites simatus Stover and Partridge 1973, and T. thomasii Cookson and Pike 1954. Examples of these morphospecies and their time distribution in southeast Australian sedimentary basins are shown in Figure 3 and Table 1, respectively. Additional specimens are illustrated in Stover and Partridge 1973, Martin 1978, Pocknall and Mildenhall 1984, Hill and Macphail 1985, Mildenhall and Pocknall 1989, Macphail et al. 1994 and Macphail 1999.Cranwellia striata (Couper) Srivastava 1966 and a related but more coarsely striate morphospecies, C. costata Mildenhall 1978 are assumed to be fossil Loranthaceae, e.g. by Askin (1990). The relationship has yet to be confirmed. However, in terms of amb shape and ornamentation, we note that both morphospecies more closely resemble pollen of Krameriaceae, a monogeneric family that is endemic to the southwest United States, Argentina and Chile (see Plate 31: Figure 378 in Heusser 1971).

Table 1. First (FA) and Last (LA) appearance of Loranthaceae-type morphospecies in southeast Australian sedimentary basins (north to south). ${ }^{1}$ Data from Macphail (1999), ${ }^{2}$ Data from Partridge (1999), ${ }^{3}$ Data from Partridge (2002).

\begin{tabular}{|c|c|c|c|c|c|c|}
\hline \multirow[b]{2}{*}{ Fossil species } & \multicolumn{2}{|c|}{ Murray ${ }^{1}$} & \multicolumn{2}{|c|}{ Gippsland 2} & \multicolumn{2}{|c|}{ Bass ${ }^{3}$} \\
\hline & FA & LA & FA & LA & FA & LA \\
\hline $\begin{array}{l}\text { Tricolpites } \\
\text { simatus }\end{array}$ & middle Eocene & late Miocene & middle Eocene & late Eocene & middle Eocene & late Eocene \\
\hline $\begin{array}{l}\text { Tricolpites } \\
\text { thomasii }\end{array}$ & late Eocene & early 0ligocene & late Mid. Eocene & late Eocene & late mid. Eocene & late Eocene \\
\hline Cranwellia striata & middle Eocene & late Miocene & late Eocene & late Eocene & late Eocene & late Eocene \\
\hline $\begin{array}{l}\text { Gothanipollis } \\
\text { bassensis }\end{array}$ & middle Eocene & late Miocene & late early Eocene & early Miocene & middle Eocene & early Miocene \\
\hline $\begin{array}{l}\text { Gothanipollis cf. } \\
\text { gothani }\end{array}$ & late Eocene & late Miocene & not recorded & not recorded & not recorded & not recorded \\
\hline $\begin{array}{l}\text { Gothanipollis } \\
\text { perplexus }\end{array}$ & late Miocene & early Pliocene & not recorded & not recorded & not recorded & not recorded \\
\hline $\begin{array}{l}\text { 'Amylotheca' } \\
\text { pliocenica }\end{array}$ & late Miocene & early Pliocene & late Pliocene & Quaternary? & not recorded & not recorded \\
\hline
\end{tabular}



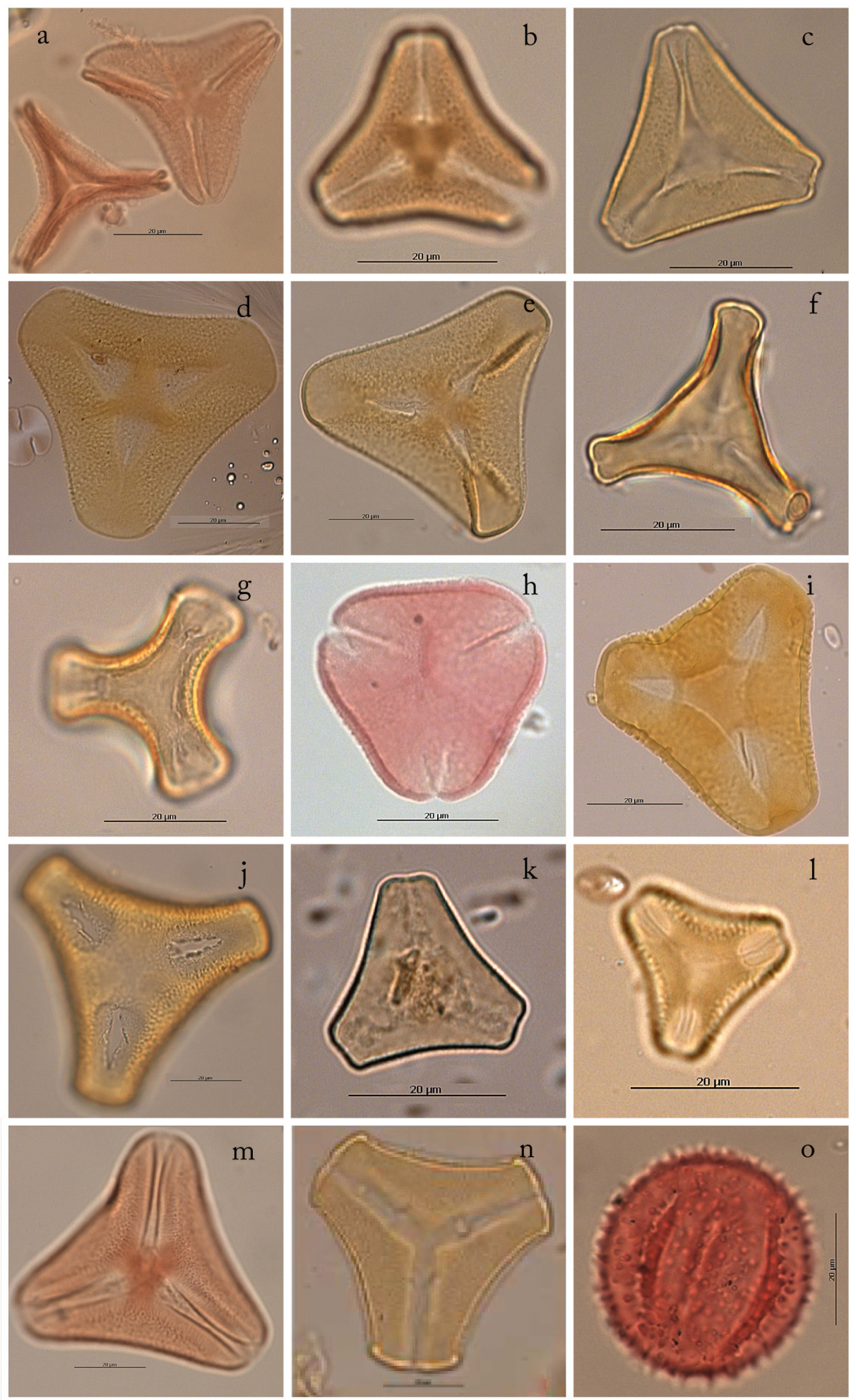

Figure 2. Photomicrographs of modern Loranthaceae pollen. a. Amyema pendula (Sieb. Ex Spreng.) Tiegh., NSW. b. Amyema congener (Sieb. Ex Schult. and Schult.f.) Tiegh., Queensland.c. Amyema miquelli (Lehm. Ex Miq.) Tiegh., NSW. d. Amylotheca dictyophleba (F. Muell.) Tiegh. Queensland. e. Decaisnina signata (F. Muell. ex benth.) Tiegh., Western Australia. f. Dactyliophora novae-guineae (F.M. Bail.) Dans, New Guinea. g. Helixanthera sessiliflora Danser, Philippines. h. Ileostylus micranthus (Hook.f.) Tiegh., New Zealand i. Lysiana sp. cf. L. spathula (Blakey) Barlow, Western Australia. j. Lysiana murrayi (Tate) Tiegh., Western Australia. k. Muellerina eucalyptoides (DC) Barlow, NSW. I. Nuytsia floribunda (Labill.) R.Br., Western Australia. m. Peraxilla colensoi (Hook.f.) Tiegh., New Zealand. n. Plicosepalus curviflorus Tiegh., South Africa. o. Tupeia antarctica (Forst.f) Cham,. and Schlect., New Zealand. 

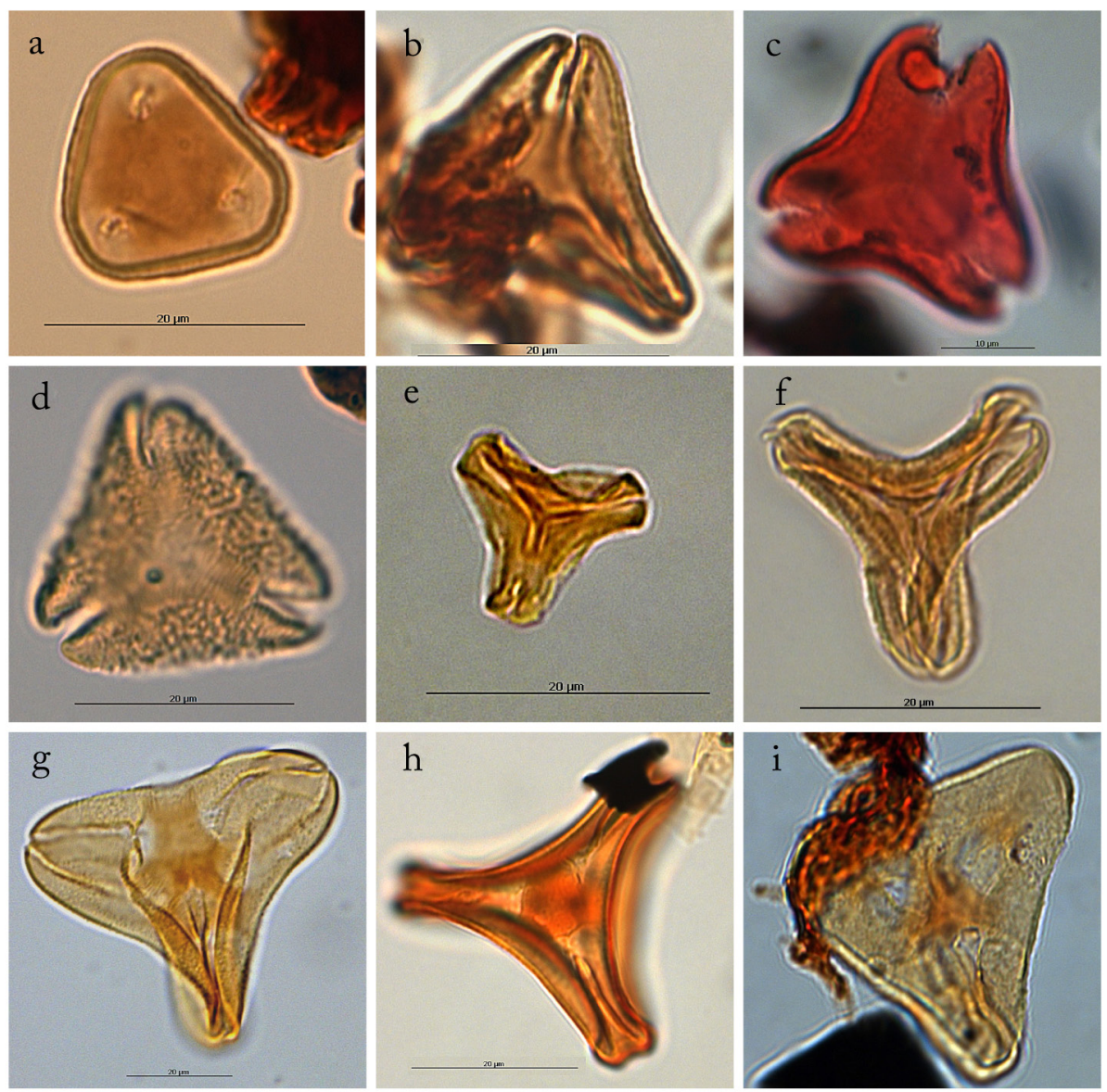

Figure 3. Fossil Loranthaceae pollen (SE Australia). a. Anacolosidites sectus. Late Eocene, BMR DDH 36-839 121-122 m, Darling Basin. b. Tricolpites simatus. Oligocene-Early Miocene, Marma-1 268-269 m, Murray Basin. c. Tricolpites simatus. Late Eocene, Hatfield-1 384 m, Murray Basin. d. Tricolpites thomasii. Late Eocene, Booligal-1 362-363 m, Murray Basin. e. Gothanipollis bassensis. Early 0ligocene, HEC DDH 5825131 ft., Tasmania. f. Gothanipollis cf. gothani. Oligocene-Early Miocene, Leaghur-1 177-178 m, Murray Basin. g. Gothanipollis perplexus. Early to late Miocene, Scotia-1 9.60 m, Murray Basin. h. Gothanipollis cf. perplexus. Early-Late Miocene, Tyntynder West-2 61-64 m, Murray Basin. i. 'Amylotheca' pliocenica. Early Pliocene, Cal Lal-1 80-81 m, Murray Basin.

A comparison with pollen produced by extant Loranthaceae genera indicates that Gothanipollis bassensis has no close living analogue in Australia due to its very small size $(<20$ $\mu \mathrm{m})$ and strongly lobate shape. Nevertheless, this species and its larger relative Gothanipollis cf. gothani bear a general resemblance to pollen produced by extant species such as Amyema congener and Dactyliophora novae-guineae (Figures 2b, f): The same qualification applies to Tricolpites simatus and T. thomasii. Ornamentation on the latter species includes coarse striae bordering the colpi (cf. Decaisnina signata and Peraxilla colensoi: (Figures 2e, m) but, as far as we are aware, no living Loranthaceae produce pollen with medium to coarse reticulate sculpturing of exine in the mesocolpial regions. The largest morphotypes found in southeast Australia, 'Amylotheca' pliocenica and Gothanipollis perplexus closely resemble pollen of Amylotheca, and Peraxilla, respectively (cf. Martin, 1978; Pocknall \& Mildenhall, 1984). The latter genus is endemic to New Zealand.

\section{Chronostratigraphic distribution of fossil Loranthaceae pollen in Tasmania}

At present, there are no records of Loranthaceae at Tertiary or Quaternary sites in southeast Tasmania, and the selection of fossil Loranthaceae pollen types illustrated in Figures 4a-o comes from sites in the north and west of the state: The stratigraphic distribution of these species in 

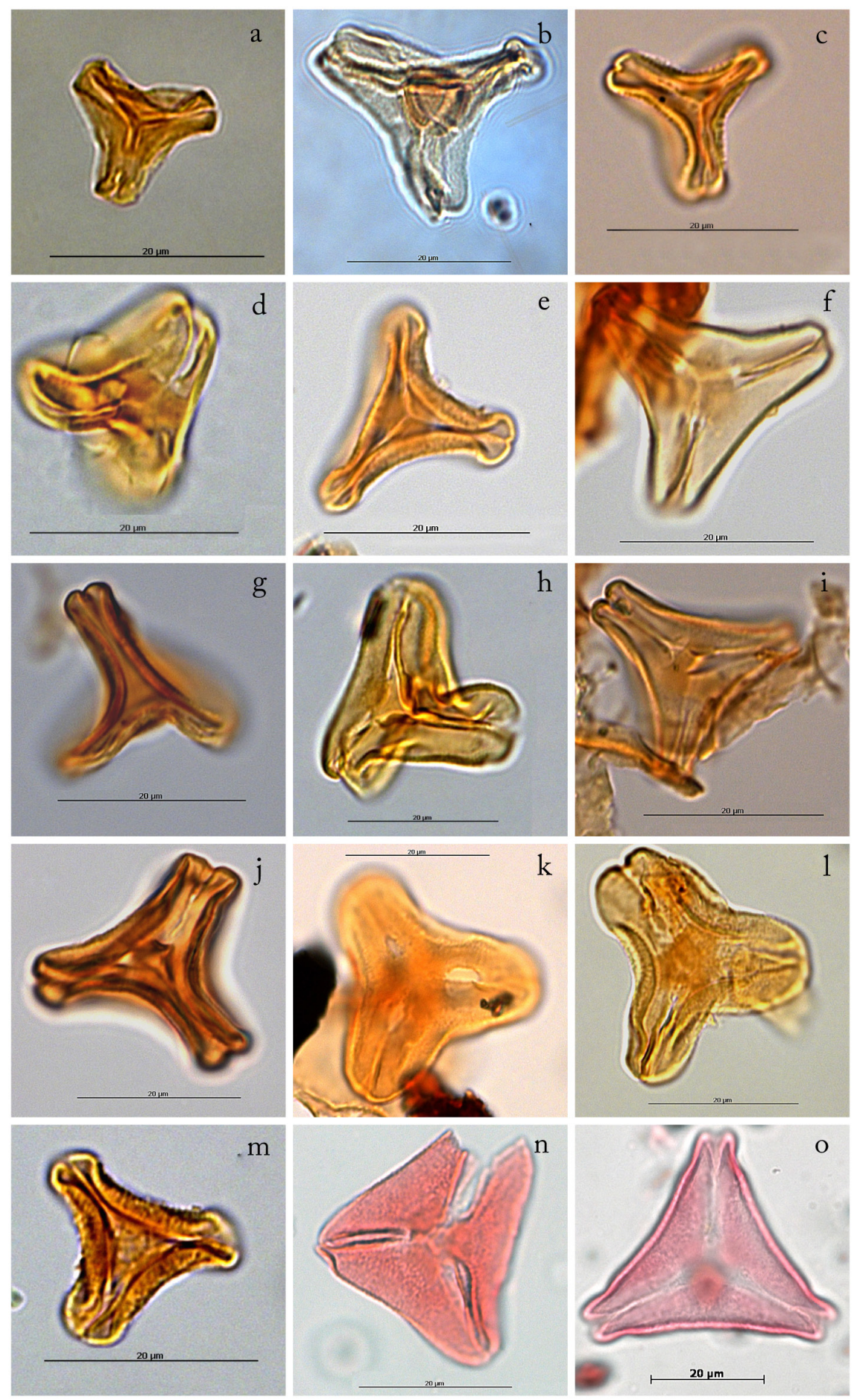

Figure 4. Fossil Loranthaceae pollen (Tasmania). a. Gothanipollis bassensis. Early Oligocene, Lemonthyme Creek DDH5825 $131 \mathrm{ft}$. b. Gothanipollis cf. bassensis. Early Oligocene, Lemonthyme Creek DDH5825 $131 \mathrm{ft}$. c. Gothanipollis bassensis. Early Eocene, outcrop Macquarie Harbour Beds, Strahan. d. Gothanipollis cf. gothani. Middle Pleistocene, Darwin Crater core $61.5 \mathrm{~m}$. e. Gothanipollis cf. gothani. Early-Middle Pleistocene, outcrop Regatta Point, Strahan f. Gothanipollis cf. gothani. Middle Pleistocene, Darwin Crater $61.5 \mathrm{~m}$. g. Gothanipollis cf. gothani. Middle Pleistocene, Darwin Crater core 61.0 m. h. Gothanipollis cf. gothani. Early Oligocene, outcrop, Lea River. i. Gothanipollis cf. gothani. Early Eocene, outcrop Macquarie Harbour Beds, Strahan. j. Gothanipollis cf. gothani. Early Oligocene, Wilmot Dam DDH 455877.5 ft. k. Gothanipollis cf. perplexus. Early Oligocene, Lemonthyme Creek DDH5825 $97 \mathrm{ft}$. I. Gothanipollis cf. perplexus. Early Oligocene, Lemonthyme Creek DDH5825 $131 \mathrm{ft}$. m. Gothanipollis cf. T. thomasi. Early-Middle Pleistocene alluvium Regatta Point. n. Gothanipollis aff. 'A.' pliocenica. Early-Middle Pleistocene alluvium, Regatta Point. o. Loranthaceae. Last Glacial, Core GC $320 \mathrm{~cm}$, Lake St. Clair. 
Table 2. Chronostratigraphic distribution of Loranthaceae pollen in the Bass and Sorell Basins and onshore sites in Tasmania.

\begin{tabular}{|c|c|c|c|c|c|c|}
\hline Basin/Area & Well/locality & Age & Zone & Morphospecies & Reference & Comment \\
\hline \multirow{14}{*}{ offshore Bass } & Chat-1 & late Eocene & $\begin{array}{l}\text { middle } \\
\text { Nothofagidites } \\
\text { asperus }\end{array}$ & $\begin{array}{l}\text { Gothanipollis } \\
\text { bassensis }\end{array}$ & $\begin{array}{l}\text { Partridge et al. } \\
2002\end{array}$ & $\begin{array}{l}\text { data from Morgan } \\
1986\end{array}$ \\
\hline & Cormorant-1 & late Eocene & $\begin{array}{l}\text { middle } \\
\text { Nothofagidites } \\
\text { asperus }\end{array}$ & $\begin{array}{l}\text { Tricolpites } \\
\text { simatus, T. } \\
\text { thomasii }\end{array}$ & $\begin{array}{l}\text { M.K. Macphail, } \\
\text { unpubl. }\end{array}$ & $\begin{array}{l}\text { see Partridge et } \\
\text { al. } 2002\end{array}$ \\
\hline & Dondu-1 & late Eocene & $\begin{array}{l}\text { middle } \\
\text { Nothofogidites } \\
\text { asperus }\end{array}$ & $\begin{array}{l}\text { Gothanipollis } \\
\text { bassensis, } \\
\text { Tricolpites } \\
\text { simatus }\end{array}$ & $\begin{array}{l}\text { Partridge et al. } \\
2002\end{array}$ & $\begin{array}{l}\text { data from Stover } \\
1973\end{array}$ \\
\hline & Kon Kon-1 & late Eocene & $\begin{array}{l}\text { middle } \\
\text { Nothofagidites } \\
\text { asperus }\end{array}$ & $\begin{array}{l}\text { Tricolpites } \\
\text { simatus, } T \text {. } \\
\text { thomasii }\end{array}$ & $\begin{array}{l}\text { Partridge et al. } \\
2002\end{array}$ & $\begin{array}{l}\text { data from Stover } \\
1973\end{array}$ \\
\hline & & middle Eocene & $\begin{array}{l}\text { lower } \\
\text { Nothofagidites } \\
\text { asperus }\end{array}$ & $\begin{array}{l}\text { Gothanipollis } \\
\text { bassensis }\end{array}$ & $\begin{array}{l}\text { Partridge et al. } \\
2002\end{array}$ & $\begin{array}{l}\text { unconfirmed } \\
\text { record }\end{array}$ \\
\hline & Narimba-1 & late Eocene & $\begin{array}{l}\text { middle } \\
\text { Nothofagidites } \\
\text { asperus }\end{array}$ & $\begin{array}{l}\text { Tricolpites } \\
\text { thomasii }\end{array}$ & $\begin{array}{l}\text { Partridge et al. } \\
2002\end{array}$ & $\begin{array}{l}\text { data from Morgan } \\
1986\end{array}$ \\
\hline & & middle Eocene & $\begin{array}{l}\text { lower } \\
\text { Nothofagidites } \\
\text { asperus }\end{array}$ & $\begin{array}{l}\text { Tricolpites } \\
\text { simatus }\end{array}$ & $\begin{array}{l}\text { Partridge et al. } \\
2002\end{array}$ & \\
\hline & Pelican-2 & early Eocene? & $\begin{array}{l}\text { Proteacidites } \\
\text { asperopolus? }\end{array}$ & $\begin{array}{l}\text { Tricolpites } \\
\text { thomasii }\end{array}$ & $\begin{array}{l}\text { Partridge et al. } \\
2002\end{array}$ & middle Eocene? \\
\hline & Pelican-5 & late Eocene & $\begin{array}{l}\text { middle } \\
\text { Nothofagidites } \\
\text { asperus }\end{array}$ & $\begin{array}{l}\text { Tricolpites } \\
\text { simatus }\end{array}$ & $\begin{array}{l}\text { Partridge et al. } \\
2002\end{array}$ & $\begin{array}{l}\text { data from Morgan } \\
1986\end{array}$ \\
\hline & Toolka-1 & late Eocene & $\begin{array}{l}\text { middle } \\
\text { Nothofagidites } \\
\text { asperus }\end{array}$ & $\begin{array}{l}\text { Tricolpites } \\
\text { simatus }\end{array}$ & $\begin{array}{l}\text { Partridge et al. } \\
2002\end{array}$ & $\begin{array}{l}\text { data from Stover } \\
1974\end{array}$ \\
\hline & Yolla-1 & late Eocene & $\begin{array}{l}\text { middle } \\
\text { Nothofagidites } \\
\text { asperus }\end{array}$ & $\begin{array}{l}\text { Tricolpites } \\
\text { thomasii }\end{array}$ & $\begin{array}{l}\text { Partridge et al. } \\
2002\end{array}$ & $\begin{array}{l}\text { see Partridge et } \\
\text { al. } 2002\end{array}$ \\
\hline & & early oligocene & $\begin{array}{l}\text { upper } \\
\text { Nothofagidites } \\
\text { asperus }\end{array}$ & $\begin{array}{l}\text { Gothanipollis } \\
\text { bassensis }\end{array}$ & $\begin{array}{l}\text { Partridge et al. } \\
2002\end{array}$ & \\
\hline & Yurongi-1 & late Eocene & $\begin{array}{l}\text { middle } \\
\text { Nothofagidites } \\
\text { asperus }\end{array}$ & $\begin{array}{l}\text { Tricolpites } \\
\text { thomasii }\end{array}$ & $\begin{array}{l}\text { Partridge et al. } \\
2002\end{array}$ & $\begin{array}{l}\text { data from Stover } \\
1973\end{array}$ \\
\hline & & middle Eocene & $\begin{array}{l}\text { lower } \\
\text { Nothofagidites } \\
\text { asperus }\end{array}$ & $\begin{array}{l}\text { Gothanipollis } \\
\text { bassensis, } \\
\text { Tricolpites } \\
\text { thomasii }\end{array}$ & $\begin{array}{l}\text { Partridge et al. } \\
2002\end{array}$ & \\
\hline $\begin{array}{l}\text { offshore } \\
\text { Sorell }\end{array}$ & Cape Sorell-1 & early Eocene? & $\begin{array}{l}\text { middle } \\
\text { Malvacipollis } \\
\text { diversus }\end{array}$ & $\begin{array}{l}\text { Tricolpites } \\
\text { simatus }\end{array}$ & $\begin{array}{l}\text { M.K. Macphail, } \\
\text { unpubl. }\end{array}$ & caved specimen \\
\hline \multirow{7}{*}{ West Coast } & Coal Head & late Quaternary & - & $\begin{array}{l}\text { Gothanipollis of. } \\
\text { gothani }\end{array}$ & $\begin{array}{l}\text { M.K. Macphail, } \\
\text { unpubl. }\end{array}$ & $\begin{array}{l}\text { reworked } \\
\text { specimen }\end{array}$ \\
\hline & Darwin Crater & $\begin{array}{l}\text { middle } \\
\text { Pleistocene }\end{array}$ & $\begin{array}{l}\text { core samples at } \\
22.0-44.7 \mathrm{~m} \text {, } \\
61.0-61.5 \mathrm{~m} . \\
\text { Absent above } \\
22 \mathrm{~m} .\end{array}$ & $\begin{array}{l}\text { Gothanipollis } \\
\text { cf. bassensis, G. } \\
\text { cf. gothani and } \\
\text { perplexus }\end{array}$ & $\begin{array}{l}\text { M.K. Macphail, } \\
\text { unpubl. } \\
\text { E.A. Colhoun, } \\
\text { unpubl. }\end{array}$ & $\begin{array}{l}\text { interval between } \\
44.7 \text { and } 61.0 \mathrm{~m} \\
\text { not yet analysed }\end{array}$ \\
\hline & King River & $\begin{array}{l}\text { middle } \\
\text { Pleistocene }\end{array}$ & $\begin{array}{l}\text { Regency site at } 0 \text {, } \\
15,40,60 \mathrm{~cm}\end{array}$ & $\begin{array}{l}\text { Gothanipollis } \\
\text { perplexus }\end{array}$ & $\begin{array}{l}\text { E.A. Colhoun, } \\
\text { unpubl. }\end{array}$ & $\begin{array}{l}\text { Fitzsimmons et al. } \\
1990\end{array}$ \\
\hline & Lowana Road & late Early Eocene & $\begin{array}{l}\text { Proteacidites } \\
\text { asperopolus }\end{array}$ & $\begin{array}{l}\text { Gothanipollis of. } \\
\text { bassensis }\end{array}$ & $\begin{array}{l}\text { M.K. Macphail, } \\
\text { unpubl }\end{array}$ & $\begin{array}{l}\text { collected by } \mathrm{G} \text {. } \\
\text { Jordan }\end{array}$ \\
\hline & Regatta Pt., & early? Quaternary & $\begin{array}{l}\text { Tubulifloridites } \\
\text { pleistocenicus? }\end{array}$ & $\begin{array}{l}\text { Gothanipollis } \\
\text { bassensis, } \\
\text { Tricolpites } \\
\text { simatus }\end{array}$ & $\begin{array}{l}\text { Hill and Macphail } \\
1985\end{array}$ & $\begin{array}{l}\text { reworked } \\
\text { specimen }\end{array}$ \\
\hline & Strahan & late early Eocene & $\begin{array}{l}\text { Proteacidites } \\
\text { asperopolus }\end{array}$ & $\begin{array}{l}\text { Gothanipollis } \\
\text { bassensis, G. cf. } \\
\text { gothani }\end{array}$ & $\begin{array}{l}\text { Macphail et al. } \\
\text { 1993a }\end{array}$ & $\begin{array}{l}\text { Macquarie Harbour } \\
\text { Beds }\end{array}$ \\
\hline & Zeehan & Oligo-Miocene & $\begin{array}{l}\text { Proteacidites } \\
\text { tuberculatus }\end{array}$ & $\begin{array}{l}\text { Gothanipollis of. } \\
\text { gothani }\end{array}$ & $\begin{array}{l}\text { M.K. Macphail, } \\
\text { unpubl. }\end{array}$ & $\begin{array}{l}\text { collected by M. } \\
\text { Pole }\end{array}$ \\
\hline
\end{tabular}


Table 2. Continued

\begin{tabular}{|c|c|c|c|c|c|c|}
\hline Basin/Area & Well/locality & Age & Zone & Morphospecies & Reference & Comment \\
\hline Northeast & Loch Aber & mid late Eocene & $\begin{array}{l}\text { Nothofagidites } \\
\text { asperus }\end{array}$ & $\begin{array}{l}\text { Gothanipollis cf. } \\
\text { bassensis }\end{array}$ & $\begin{array}{l}\text { M.K. Macphail, } \\
\text { unpubl. }\end{array}$ & \\
\hline \multirow{6}{*}{$\begin{array}{l}\text { northwest } \\
\text { Central } \\
\text { Plateau }\end{array}$} & Cradle Mt. & recent & $\begin{array}{l}\text { core LDGS at 7, 33, } \\
38 \mathrm{~cm}\end{array}$ & Loranthaceae & Dyson 1995 & Dove Lake \\
\hline & Lake St. Clair & late Pleistocene & core CG at $320 \mathrm{~cm}$ & $\begin{array}{l}\text { Loranthaceae cf. } \\
\text { Amyema }\end{array}$ & F. Hopf, unpubl. & Narcissus Bay \\
\hline & $\begin{array}{l}\text { Lemonthyme } \\
\text { Creek }\end{array}$ & early 0ligocene & $\begin{array}{l}\text { Proteacidites } \\
\text { tuberculatus }\end{array}$ & $\begin{array}{l}\text { Gothanipollis } \\
\text { bassensis, G. cf. } \\
\text { gothani, } \\
\text { G. perplexus, G. } \\
\text { cf. perplexus. }\end{array}$ & $\begin{array}{l}\text { Macphail et al. } \\
\text { 1993b } \\
\text { M.K. Macphail, } \\
\text { unpubl. }\end{array}$ & HEC DDH 5825 \\
\hline & Lea River & Oligo-Miocene & $\begin{array}{l}\text { Proteacidites } \\
\text { tuberculatus }\end{array}$ & $\begin{array}{l}\text { Gothanipollis cf. } \\
\text { gothani }\end{array}$ & $\begin{array}{l}\text { M.K. Macphail, } \\
\text { unpubl. }\end{array}$ & collected by R. Hill \\
\hline & Tyndall Ranges & Holocene & - & $\begin{array}{l}\text { Gothanipollis cf. } \\
\text { gothani }\end{array}$ & $\begin{array}{l}\text { Macphail and } \\
\text { Colhoun } 1982\end{array}$ & $\begin{array}{l}\text { peat in summit } \\
\text { tarn }\end{array}$ \\
\hline & Wilmot Dam & early 0ligocene & $\begin{array}{l}\text { Proteacidites } \\
\text { tuberculatus }\end{array}$ & $\begin{array}{l}\text { Gothanipollis } \\
\text { bassensis, G. cf. } \\
\text { gothani }\end{array}$ & $\begin{array}{l}\text { Macphail and Hill } \\
1994\end{array}$ & HEC DDH 4558 \\
\hline
\end{tabular}

the Bass Basin and onshore sites in Tasmania is given in Table 2. We emphasise that absence of evidence is not necessarily evidence of absence. Reasons are small morphospecies such as Gothanipollis bassensis are easily overlooked, especially if partly obscured by plant detritus, and also can be lost during processing if the organic extracts are filtered through 10 to $20 \mu \mathrm{m}$ sieve cloth. Nevertheless, the records are adequate to confirm (numerical ages after Ogg et al. 2008):

1. The oldest reliable records of Loranthaceae species in Tasmania (and probably Australia as a whole) are specimens of Gothanipollis bassensis and Tricolpites simatus preserved in the late early Eocene (ca. 50.5-51.5 million years ago) Macquarie Harbour Formation at Regatta Point and Lowana Road near Strahan, western Tasmania. Specimens of Tricolpites simatus in the same sections appear to pre-date the first appearance of the species in the offshore Bass and Gippsland Basins in Bass Strait, although the converse applies to Gothanipollis bassensis. Both species grew in complex evergreen mesotherm to megatherm (subtropical-tropical) rainforest communities (Macphail 2007) that began developing at relatively high $\left(60-65^{\circ} \mathrm{S}\right.$ ) palaeolatitudes in southern Australia following rapid greenhouse warming of the planet by $5^{\circ} \mathrm{C}$ to $10^{\circ} \mathrm{C}$ at the Paleocene/Eocene boundary ca. 55.8 million years ago (PaleoceneEocene Thermal Maximum) and subsequent hyperthermal events that characterised the Early Eocene (see Dickens 2009). Presumed reworked specimens occur in Quaternary deposits at Coal Head in Macquarie Harbour and in cuttings along the road between Strahan and Lowana Road, e.g. behind the Cool Store at Regatta Point (Macphail et al., 1993a)

2. Except in the offshore Bass Basin and onshore extensions in northern Tasmania, middle to late Eocene deposits are rare (see Macphail 2007) and there is insufficient evidence to determine whether Loranthaceae species such as Tricolpites thomasii ever extended southwards into the mountainous interior or along the west or east coasts. Stratigraphic evidence from the Bass Basin indicates Tricolpites thomasii became extinct at about the major cooling event that marks the Eocene/Oligocene boundary at 33.9 million years ago (references in Wei 1991; Exon et al. 2004). Tricolpites simatus is recorded in early Oligocene sediments at Lemonthyme Creek (see Plate 5, Figure D in Macphail and Hill 1994): Gothanipollis bassensis survived into Oligo-Miocene time in western Tasmania and also in the Bass, Gippsland and Murray Basins in mainland southeast Australia. 
3. Gothanipollis perplexus and a complex of morphotypes centred on this species and $G$. gothani first appear in the early Oligocene in Tasmania, with the majority of records coming from the disputed glacial sequences at Lemonthyme Creek and Wilmot Dam in the Mersey-Forth Valleys (cf. Paterson 1965; Paterson et al. 1967; Fitzsimons et al. 1993; Macphail et al. 1993b; Macphail and Hill 1994). These and other records from correlative sediments from the Lea River and near Zeehan provide compelling evidence that at least three species of Loranthaceae were growing in Nothofagus warm temperate rainforest in western Tasmania during the late Paleogene: It is possible that the host trees included Nothofagus spp. (cf. Vidal-Russell and Nickrent 2008b).

4. Gothanipollis perplexus may have reached Tasmania by trans-oceanic dispersal, since the morphospecies first occurs in late Eocene deposits in New Zealand (Pocknall and Mildenhall 1984) but is absent in late Eocene deposits at Prydz Bay, East Antarctica (see Macphail and Truswell, 2004; Truswell and Macphail 2008). The Lemonthyme Creek records of Gothanipollis perplexus and G. cf. perplexus are significantly older than the earliest records of Gothanipollis perplexus in the epicontinental Murray Basin in southeast Australia (Table 2). It is unlikely any of the currently known Gothanipollis species evolved in Tasmania, although the migration route(s) are unknown.

5. Fossil Loranthaceae pollen have not been recorded in the late Oligocene-early Miocene cool-climate flora at Monpeelyata $(920 \mathrm{~m}$ elevation) on the eastern Central Plateau (Macphail et al. 1991), nor at the one known late Pliocene site in western Tasmania, the Linda Valley palaeosol (Macphail et al. 1995).

6. At least one fossil species, 'Amylotheca' pliocenica, which first appears in the late Pliocene in eastern Australia and New Guinea, did not extend as far south as Tasmania or the Bass and Gippsland Basins (Macphail 1997, 2007). The reason for this may be cool to cold climates, since Amylotheca is restricted to coastal rainforest from central NSW northwards into southern New Guinea (Barlow 1966; Henty 1995). Fossil specimens are found in late Pliocene assemblages from the northwest Murray Basin (Scotia Province) to the Atherton Tableland in northeast Queensland Australia (Kershaw and Sluiter 1982; Macphail 1999).

7. Specimens belonging to the complex of morphotypes centred on Gothanipollis bassensis, G. gothanii and G. perplexus are rare but ubiquitous in (1) the middle Pleistocene Regency interglacial sequence in the King River Valley near Queenstown (Fitzsimons et al. 1990), and (2) in the lower ca. $40 \mathrm{~m}$ of a $62 \mathrm{~m}$ thick sequence of lacustrine clays at Darwin Crater in the Andrew River Valley ca. $20 \mathrm{~km}$ east of Macquarie Harbour (Howard and Haines, 2007). The lake sediments show normal magnetic polarity, the Brunhes-Matuyama Boundary is not recorded (Barton 1987) and, based on K/Ar fission-track dates of 0.82 million years ago on a siliceous impact glass (Darwin Glass) associated with the crater, are middle to late Pleistocene (Lo et al. 2002): The section has yet to be fully pollenanalysed, but Loranthaceae pollen commence at $22.0 \mathrm{~m}$ and are consistently present down to $44.7 \mathrm{~m}$, and occur between $61.0 \mathrm{~m}$ and $61.5 \mathrm{~m}$, immediately above the contact with poorly sorted, coarser crater fill deposits (Colhoun 1988; Colhoun and Van der Geer 1998; E.A. Colhoun and M.K. Macphail, unpubl. data). The section between $44.7 \mathrm{~m}$ and $61 \mathrm{~m}$ has not been analysed but we anticipate Loranthaceae pollen will be present.

8. The Regency sequence represents the replacement of montane scrub rainforest by Nothofagus cunninghamii-Podocarpaceae cool temperate rainforest. Specimens of Gothanipollisperplexus 
and G.cf.perplexus occurring between c. $22 \mathrm{~m}$ and $45 \mathrm{~m}$ in Darwin Crater mostly occur in cool temperate rainforest pollen assemblages dominated by Huon Pine Lagarostrobos franklinii), associated with lesser amounts of Subantarctic Beech (Nothofagus cunninghamii) and Celery-top Pine (Phyllocladus aspleniifolius) and occasional tree-fern (Cyathea spp.) spores, but are absent in assemblages representing lower, more open vegetation types such as wet scrub/heath and herbfield (E.A. Colhoun, unpubl. data). A not unreasonable interpretation is that mistletoes were growing on trees at the margins of temperate rainforest during the middle Pleistocene and the host species may have included Lagarostrobos and Nothofagus.

9. The top $20 \mathrm{~m}$ of sediment in Darwin Crater is believed to have accumulated between Oxygen Isotope Stages (OIS) 1 to OIS 7, indicating that Loranthaceae became locally? extinct in the Andrew River Valley sometime before the OIS 7 Interglacial, i.e. before $0.24-0.25$ million years ago.

10. Four specimens of Loranthaceae pollen have been found in last glacial and postglacial sediments in western Tasmania - at Lake St. Clair on the Central Plateau (F. Hopf, unpubl. data), at Dove Lake, Cradle Mountain (Dyson 1995), and at an unnamed tarn on the summit of the Tyndall Ranges (Macphail and Colhoun 1982). Since the two Dove Lake specimens occur in near surface muds, it is equally likely that the Lake St. Clair and Tyndall Ranges specimens have been long-distance transported, e.g. by migrating birds.

\section{Discussion}

All mistletoe lineages within the Santalales appear to have evolved from root parasite ancestors (Vidal-Russell and Nickrent, 2008a, b). Molecular dating of genera divergence times indicates that the 'aerial' parasitic habit evolved in the Misodendraceae sometime between ca. 80 and 25 million years ago (early Campanian to late Oligocene), in the Viscaceae between ca. 72 and 43 million years ago (late Campanian to middle Eocene), in the Santaleae between ca. 46 and 53 million years ago (middle to early Eocene), in Amphorogyneae between ca. 53 and 22 million years ago (early Eocene to early Miocene), and the Loranthaceae at ca, 27 to 28 million years ago (mid Oligocene). On this model, 'Amylotheca' pliocenica and? Gothanipollis perplexus are likely to represent hemi-parasitic shrublets growing on and within the branches of trees and shrubs: Whether the Eocene parent plants of Gothanipollis bassensis, G. cf. gothani, Tricolpites simatus, T. thomasii and early Oligocene parent plant(s) of G. cf. perplexus were root parasites or represent wholly extinct clades of aerial parasites is unknown, and likely to remain so without macrofossil evidence.

Pollen evidence for the origins of the Loranthaceae per se is complicated by the uncertain evolutionary relationship of the family to late Cretaceous taxa, in particular Cranwellia, a morphogenus that first occurs in the Campanian in Antarctica (Askin 1990), and Aquilapollenites, one of many extinct angiosperm genera within the Triprojectacites group that dominated Northern Hemisphere Maastrichtian palynofloras (see Farabee 1993). However, there is compelling pollen evidence in the form of an extinct morphospecies of Anacolosa (Anacolosidites acutullus Cookson and Pike 1954) that one clade within the Santalales was present in northwest Australia during the late Cretaceous (see Macphail 2007). The Anacolosidites species that most closely resembles modern Loranthaceae pollen (A. sectus Stover and Partridge 1973: Figure 3a) does not appear before the middle Eocene in southeast Australia. Whether late Cretaceous morphotypes assigned to Cranwellia and G. gothani ssp. plicus in China (see Plate 150: Figures 1-3 in Song et al. 2004) are in fact fossil members of the Loranthaceae has yet to be confirmed. 
Phylogenetic and fossil evidence (Vidal-Russell and Nickrent 2008a, b) suggests that the family evolved in East Gondwana (Australia-New Guinea, New Zealand, South America) during the late Cretaceous, with relatively late dispersals into Africa, India, Asia and Europe. For example, the genus Loranthus occurs in Europe and Asia, but the split between it and Cecarria (a monotypic genus spanning Australia to the Philippines) has been estimated at less than 30 million years ago. Several other clades of similar or younger age have members in both Australasia and Asia (Vidal-Russell and Nickrent 2008a, b). Nevertheless, morphospecies resembling modern Loranthaceae pollen have been recorded from early to late Eocene deposits in northern and central Europe, the United States and China (references in Muller 1981; Song et al.2004) and it is possible that the family first appeared in both hemispheres about the same time but the ancient Northern Hemisphere lineages subsequently became extinct. Whether such speculations are an artefact of inadequate fossil data is unknown. However, it is tempting to hypothesise that the migration of birds and possibly bats (see Archer et al. 1991:137, 230) across the equator is a plausible reason for the near-contemporaneous first appearance of Loranthaceae in both hemispheres. This conjecture is reinforced by records of Loranthaceae pollen at sites where alternative modes of transport are improbable. Examples are the nowsubmerged Ninetyeast Ridge in the remote Indian Ocean where Gothanipollis cf. gothani occurs in Oligocene sediments (see Kemp and Harris 1975), and the summits of mountains in tropical South America, where Loranthaceae pollen has been recovered from modern snow samples (see Reese et al.2003).

The data demonstrate that fossil species of Loranthaceae in Tasmania were tolerant of megatherm and then mesotherm climates during the Paleogene. For example, macro- and microfossils from late-early Eocene deposits at Regatta Point and Lowana Road confirm that the tropical mangrove palm Nypa lined tidal channels within Macquarie Harbour (Partridge 1976; Pole and Macphail 1997). Other mesotherm-megatherm rainforest taxa associated with Tricolpites simatus and Gothanipollis bassensis include Anacolosa, Arecaceae (Arecipites, Dicolpopollis), Ascarina, Cunoniaceae, Dysoxlum, Freycinetia, Ilex, Meliaceae and Strasburgeriaceae (Bluffopollis scabratus). In contrast, Loranthaceae pollen (Gothanipollis bassensis) found at the middle-late Eocene Loch Aber site in northeast Tasmania (M.K. Macphail, unpubl. data) grew in floristically diverse, warm temperate rainforest dominated by Nothofagus and gymnosperms that are now extinct in Tasmania. For example, trees included a species similar to Nothofagus moorei, now endemic to NSW, Podocarpaceae, including Acmopyle, now endemic to New Caledonia and Fiji, and an extinct Araucaria belonging to the South American section Columba: Average leaf lengths in the Loch Aber fossil flora are smaller than in early Eocene floras, consistent with a general decrease in mean air temperatures from the early to middle Eocene (Hill and Carpenter 1991; Carpenter et al. 1994).

Major global cooling that followed subsidence of the South Tasman Rise and Drake Passage to abyssal depths and formation of the Circumantarctic Current during the Eocene-Oligocene transition meant Loranthaceae species growing in cool temperate rainforest in the MerseyForth River Valleys had become resilient to even cooler (microtherm) conditions by about 33 million years ago (see Macphail et al. 1993b; Exon et al. 2004). Whether Loranthaceae were continuously present in Tasmania from the early Oligocene to Early Miocene and Quaternary is unclear due to lack of tightly dated palynosequences south of the offshore Bass Basin. Clusters of Gothanipollis spp. found in the basal $40 \mathrm{~m}$ of lake sediments in Darwin Crater and in the Regency Interglacial deposit indicate that Loranthaceae were growing in cool temperate rainforest in western Tasmania during the middle Pleistocene. We note that these rainforest communities differed from modern Nothofagus cunninghamii-Podocarpaceae closed forest in Tasmania in two minor aspects only - the tree-fern stratum was dominated by Cyathea spp., not Dicksonia antarctica, and in some areas the subcanopy stratum included several small tree 
and shrub genera that are now restricted to mainland Australia (Haloragodendron, Quintinia, Symplocos).

A number of taxa now endemic to South America became established in Tasmania during the Paleogene. Examples (fossil species in parentheses) are: Nothofagus subgenus Nothofagus (Nothofagidites flemingii) in the earliest Paleocene, Embothrium (Granodiporites nebulosus Stover and Partridge 1973) in the earliest Oligocene, and the tribe Mutisieae of the Asteraceae (Mutisiapollis patersonii Macphail and Hill 1994) and the ground fern Lophosoria quadrapinnata (Cyatheacidites annulatus Cookson 1947) by the early Oligocene. Given the observed close relationship of Misodendron with Nothofagus in southern South America, it seems reasonable to speculate that this mistletoe family also could have been present in Tasmania in the past.

Misodendron pollen are distinctive due to their sphaeroidal shape and apiculate sculpture. However, confirming the presence of this genus in Tasmania will be difficult since the small size $(19-22 \mu \mathrm{m})$ of its pollen grains means specimens can be easily lost during processing, or overlooked, or the pollen type may have evolved after the split between Misodendron and other Santalaceae. Fossil specimens are likely to be assigned to the morphogenus Compositoipollenites Potonié ex Potonié 1960 (see Macphail and Cantrill 2006). At present, the only species of Compositoipollenites that has been formally described in Australia is C. tarrogoensis Truswell and Owen 1988 from a middle Eocene palynosequence at Bungonia on the Southern Tablelands of NSW (cf. Plate 38, Figure 462 in Heusser 1971, Figure 8 H-U in Truswell and Owen 1988). Similar morphotypes occur in late Maastrichtian sediments in the Bonaparte Basin in northern Australia, an early Eocene sample from the Cape Sorell-1 petroleum exploration well in the offshore Sorell Basin (Figure 1), and a probable early Eocene deposit in the Styx River Valley in southeast Tasmania (Macphail 2007). Viscum pollen are easily recognised by the presence of stout spines (see Tafel 35: 1-4 in Beug 2004), but, as yet, no fossil specimens have been recorded in Australia (G.S. Hope pers. comm.).

Reconstructing and interpreting the history of mistletoes in Tasmania will continue to depend on the slow accumulation of microfossil evidence, often from sites that have been uncovered by chance events (see Hill 1987). We consider it unlikely that palynologists working on Tertiary to late Quaternary deposits will have mis-identified or overlooked larger morphospecies such as Gothanipollis perplexus or 'Amylotheca' pliocenica, and therefore conclude that, even when establishment was successful, Loranthaceae always were rare elements in the Tasmanian flora. Why this should be so is more likely to be a consequence of cool/wet climates than a lack of suitable host species. If correct, then any climatic barriers that have prevented the establishment of mistletoes during the Holocene may well be breached through warming/ drying of Tasmania in the near future.

\section{Acknowledgements}

We express our thanks to Dr Mike Fletcher (Department of Archaeology and Natural History, Australian National University) for his useful comments on an earlier draft of the paper.

\section{References}

Archer, M., Hand, S.J. and Godthelp, H. 1991. Riversleigh: The Story of Animals in Ancient Rainforests of Inland Australia. Sydney: Reed Books.

Askin, R.A. 1990. Campanian to Paleocene spore and pollen assemblages of Seymour Island, Antarctica. Review of Palaeobotany and Palynology 65:105-113.

Barlow, B.A. 1984. Loranthaceae. In: George, A.D. (ed), Flora of Australia Vol. 22, pp. 68-131. 
Canberra: Australian Government Publishing Service.

Barton, C. 1987. Palaeomagnetism. Age of the Darwin Crater. Bureau of Mineral Resources Yearbook (1987): 36-37.

Beug, H-J. 2004. Leitfaden der Pollenbestimmung für Mitteleuropa und angrenzende Gebiete. Munich: Verlag.

Carpenter, R.J., Hill, R.S. and Jordan, G.J. 1994. Cenozoic vegetation in Tasmania: macrofossil evidence. In: Hill, R.S. (ed), History of the Australian Vegetation: Cretaceous to Recent, pp. 276-298. Cambridge: Cambridge University Press.

Colhoun, E.A. 1988. Cainozoic Vegetation of Tasmania. Department of Geography, University of Nerwcastle Special Paper ISBN 0725906219.

Colhoun, E.A. and van de Geer, G. 1998. Pollen analysis of 0-20 m of Darwin Crater, western Tasmania. In: Horle, S. (ed), International Project on Palaeolimnology and Late Cenozoic Climate Nerwsletter 11:68-89.

Dickens, G.R. 2009. Early Cenozoic hyperthermals: the sedimentary record of rapid global warming and massive carbon input. CSEG Recorder (February):28-32.

Dyson, W.D. 1995. A pollen and vegetation history from Lake Dove, western Tasmania. BSc. Honours thesis, University of Newcastle (unpubl.).

Erdtman, G. 1966. Pollen Morphology and Plant Taxonomy: Angiosperms. New York: Hafner Publishing.

Exon, N.F., Kennett, J.P. and Malone, M.J. 2004. 1. Leg 189 synthesis: Cretaceous-Holocene history of the Tasmanian Gateway. In: Exon, N.F., Kennett, J.P. and Malone, M.J. (eds), Proceedings ODP Scientific Results 189:1-37.

Farabee, M.J. 1993. Morphology of triprojectate fossil pollen: form and distribution in space and time. Botanical Review 59:211-249.

Fitzsimons, S.J., Colhoun, E.A., van de Geer, G. and Hill, R.S. 1990. Definition and character of the Regency Interglacial and Early-Middle Pleistocene stratigraphy in the King Valley, western Tasmania. Boreas 19:1-15.

Fitzsimons, S.J., Macphail, M.K., Colhoun, E.A., Kiernan, K. and Hannan, D. 1993. Glacial climates in the Antarctic region during the late Paleogene: evidence from northwest Tasmania: Comment and reply. Geology 21:958-959.

Heusser, C.J. 1971. Pollen and Spores of Chile. Tucson: University of Arizona Press.

Hill, R.S. 1987. Discovery of Nothofagus fruits corresponding to an important Tertiary pollen type. Nature 327:56-58.

Hill, R.S. and Macphail, M.K. 1985. Reconstruction of the Oligocene vegetation at Pioneer, northeast Tasmania. Alcheringa 7:281-299.

Hill, R.S. and Carpenter, R.J. 1991. Evolution of Acmopyle and Dacrycarpus (Podocarpaceae) foliage as inferred from macrofossils in south-eastern Australia. Australian Systematic Botany 4:449-479.

Howard, K.T. and Haines, P.W. 2007. The geology of Darwin Crater. Earth and Planetary Science Letters 260:328-339.

Kemp, E.M. and Harris, W.K. 1975. The vegetation of Tertiary islands on the Ninetyeast Ridge. Nature 258:303-307.

Kershaw, A.P. and Sluiter,I.R. 1982. Late Cenozoic pollen spectra from the Atherton Tableland, north-eastern Australia. Australian Journal of Botany 30:279-295.

Lo, C.H., Howard, K.T., Chung, S.L. and Meffre, S. 2002. Laser fusion-40/argon-39 ages of Darwin impact glass. Meteoritics and Planetary Science 37:1555-1562.

Macphail, M.K. 1999. Palynostratigraphy of the Murray Basin, inland southeastern Australia. Palynology 23:199-242.

Macphail,M.K. 2007. Australian Palaeoclimates Cretaceous to Tertiary. A review of palaeobotanical 
and related evidence to the year 2000. CRC-LEME Open File Report 151 (Special Volume ISBN 192103975 2).

Macphail,M.K. and Colhoun, E.A.1982.“Tarn Shelf”, Tyndall Ranges, West Coast Tasmania. Department of Geography, Faculty of Military Studies, University of Nerw South Wales Occasional Paper 33:107-108.

Macphail, M.K., Hill, R.S., Forsyth, S.M. and Wells, P.M. 1991. A Late Oligocene-Early Miocene cool climate flora in Tasmania. Alcheringa 15:87-106.

Macphail, M.K., Jordan, G.J. and Hill, R.S. 1993a. Key periods in the flora and vegetation in western Tasmania 1. The early-middle Pleistocene. Australian Journal of Botany 41:673707.

Macphail, M.K., Colhoun, E.A., Kiernan, K. and Hannan, D. 1993b. Glacial climates in the Antarctic region during the late Paleogene: evidence from northwest Tasmania, Australia. Geology 21:145-148.

Macphail, M.K., Alley, N.F., Truswell, E.M. and Sluiter, I.R.K. 1994. Early Tertiary vegetation: evidence from spores and pollen. In: Hill, R.S. (ed), History of the Australian Vegetation: Cretaceous to Recent, pp. 189-261. Cambridge: Cambridge University Press.

Macphail, M.K. and Hill, R.S. 1994. K-Ar dated palynofloras in Tasmania 1: Early Oligocene Proteacidites tuberculatus Zone sediments, Wilmot Dam, northwestern Tasmania. Papers and Proceedings of the Royal Society of Tasmania 128:1-15.

Macphail, M.K., Colhoun, E.A. and Fitzsimons, S.J. 1995. Key periods in the evolution of the Cenozoic vegetation and flora in western Tasmania: the Late Pliocene. Australian Journal of Botany 43:505-526.

Macphail, M.K. and Truswell, E.M. 2004. Palynology of Site 1166, Prydz Bay, East Antarctica. Proceedings of the Ocean Drilling Program. Scientific results 188:1-29.

Macphail, M.K. and Cantrill, D.J. 2006. Age and implications of the Forest Bed, Falkland Islands, southwest Atlantic Ocean: evidence from fossil pollen and spores. Palaeogeography, Palaeoclimatology, Palaeoecology 240:602-629.

Martin, H.A. 1978. Evolution of the Australian flora and vegetation through the Tertiary: evidence from pollen. Alcheringa 2:181-202.

Mildenhall, D.C. 1978. Cranwellia costata n.sp. and Podosporites erugatus n.sp. from Middle Pliocene (?Early Pleistocene) sediments, South Island, New Zealand. Journal of the Royal Society of New Zealand 8:253-274.

Mildenhall,D.C. and Pocknall,D.T. 1989. Miocene-Pleistocene spores and pollen from central Otago, South Island, New Zealand. New Zealand Geological Survey Palaeontological Bulletin 59:1-128.

Moar, N.T.1993. Pollen grains of Nerw Zealand Dicotyledonous Plants. Lincoln: Manaaki Whenua Press.

Muller, J. 1981. Fossil pollen records of extant angiosperms. Botanical Review 47:1-142.

Nickrent, D.L., Malécot, V., Vidal-Russell, R. and Der, J.P. 2010. A revised classification of the Santalales. Taxon 59: 538-558.

Ogg, J.G., Ogg, G. and Gradstein, F.M. 2008. The Concise Geologic Time Scale. Cambridge: Cambridge University Press.

Paterson, S.J. 1965. Pleistocene drift in the Mersey and Forth Valleys - probability of two glacial stages. Papers and Proceedings of the Royal Society of Tasmania 99:115-124.

Paterson, S.J.,Duigan, S.L. and Joplin, G.A.1967. Notes on Pleistocene deposits at Lemonthyme Creek in the Forth Valley. Papers and Proceedings of the Royal Society of Tasmania 101:221225.

Partridge, A.D., Trigg, K., Montgomerie, N.R. and Blevin, J. 2002. Review and compilation of open file micropalaeontology and palynology data from offshore Tasmania. Geoscience 
Record 2002 [CD 3 of 7].

Pocknall, D.T. and Mildenhall, D.C. 1984. Late Oligocene-early Miocene spores and pollen from Southland, New Zealand New Zealand Geological Survey Palaeontological Bulletin 51:1-66.

Reese, C.A., Liu, K-b and Mountain, K.R. 2003. Pollen dispersal and deposition on the ice cap of Volcan Parinacota, southwestern Bolivia. Arctic, Antarctic and Alpine Research 35:469474.

Song, Z, Wang, W. and Huan, F. 2004. Fossil pollen records of extant angiosperms in China. Botanical Review 70:425-458.

Stover, L.E. and Partridge, A.D. 1973. Tertiary and Late Cretaceous spores and pollen from the Gippsland Basin, southeastern Australia. Proceedings of the Royal Society of Victoria 85:237-286.

Truswell, E.M. and Owen,J.A. 1988. Eocene pollen from Bungonia, New South Wales. Memoir Association of Australasian Palacontologists 5:259-284.

Truswell, E.M. and Macphail, M.K. 2008. Polar forests on the edge of extinction: what does the fossil spore and pollen evidence from East Antarctica say? Australian Systematic Botany 22:57-106.

Vidal-Russell, R. and Nickrent, D.L. 2008a. The first mistletoes: origins of aerial parasitism in Santalales. Molecular Phylogenies and Evolution 47:523-537.

Vidal-Russell, R. and Nickrent, D.L. 2008b. Evolutionary relationships in the showy mistletoe family (Loranthaceae). American Journal of Botany 95:1015-1029.

Wei, W. 1991. Evidence for an earliest Oligocene abrupt cooling in the surface waters of the Southern Ocean. Geology 19:780-783. 